\title{
Induction of Phytoalexins Gliceoline and Proteins Related to Defense in Soybean Cotyledon Treated With Yeast
}

\author{
Eloisa Lorenzetti ${ }^{1}$, Jeferson Carlos Carvalho ${ }^{2}$, Alfredo José Alves Neto ${ }^{2}$, Camila Hendges ${ }^{2}$, Taís Regina Kohler ${ }^{2}$, \\ Tatiane Calandrino da Mata ${ }^{2}$, João Cezar Alves da Silva ${ }^{2}$, Olivia Diulen Costa Brito ${ }^{2}$, Vanessa de Oliveira Faria ${ }^{2}$, \\ Lorraine Tomim Feroldi ${ }^{1}$, Lívia Maria Lemos Hoepers ${ }^{3} \&$ Odair José Kuhn ${ }^{2}$ \\ ${ }^{1}$ Agricultural Science Center, Federal University of Paraná, Palotina, Paraná, Brazil \\ ${ }^{2}$ Agricultural Science Center, State University of Western Paraná, Marechal Cândido Rondon, Paraná, Brazil \\ ${ }^{3}$ Agricultural Science Center, Federal University of Paraná, Curitiba, Paraná, Brazil \\ Correspondence: Eloisa Lorenzetti, Center of Agrarian Science, Federal University of Paraná, Palotina, Paraná, \\ Brazil. Tel: 55-45-99911-5500. E-mail: eloisa-lorenzetti@hotmail.com
}

Received: September 23, 2020

doi:10.5539/jas.v12n12p156
Accepted: October 27, $2020 \quad$ Online Published: November 15, 2020

URL: https://doi.org/10.5539/jas.v12n12p156

\begin{abstract}
Yeasts can induce mechanisms of plant resistance due to compounds with eliciting characteristics, so the aim of this work was to evaluate the effect of yeast on the induction of phytoalexins gliceoline, peroxidase, polyphenoloxidase and phenylalanine ammonia-lyase from soy cotyledons. To determine the defense enzymes, soybean seeds were sown and the cotyledons treated with sterile distilled water, Cryptococcus laurentii (AH 03-1), Pichia guilliermondii (AH 16-2), Rhodotorula glutinis (AH 14-3), Sporidiobolus johnsonii (AH 16-1) and Zygoascus hellenicus (AH 14-1). Biochemical analyzes of the formation of phytoalexins and the activity of the enzymes peroxidase, polyphenoloxidase, phenylalanine ammonia-lyase and total proteins were performed. For phytoalexins glycerolins the yeasts Cryptococcus laurentii (AH 03-1) and Zygoascus hellenicus (AH 14-1) promoted an increase of $83.65 \%$ and $78.75 \%$ in the formation of this compound. Cryptococcus laurentii (AH 03-1) increased peroxidase activity by $36.84 \%$, while for polyphenoloxidase, the Pichiaguilliermondii e yeasts (AH 16-2), Rhodotorula glutinis (AH 14-3), Sporidiobolus johnsonii (AH 16-1) and Zygoascus hellenicus (AH $14-1$ ), increased the activity of this enzyme by $33.33 \%, 28.00 \%, 33.33 \%$ and $33.33 \%$, respectively. For phenylalanine ammonia-lyase, Cryptococcus laurentii (AH 03-1) and Zygoascushellenicus (AH 14-1) promoted an increase of $75.57 \%$ and $78.86 \%$, respectively, in their activity. The results demonstrate the potential of yeasts studied in the induction of phytoalexins glyceolins and in the activity of peroxidase, polyphenoloxidase and phenylalanine ammonia-lyase in soybean cotyledons.
\end{abstract}

Keywords: Glycine max, induction of resistance, peroxidase, polyphenoloxidase, phenylalanine ammonia-lyase

\section{Introduction}

The soybean (Glycine $\max$ (L.) Merrill), is a very important crop (Hirakuri \& Lazzarotto, 2014), host of several pathogens that affect both the productivity and quality of the final product (Juhász et al., 2013).

In order to reduce disease losses, control methods are used, some of which are classified as alternative (Carneiro et al., 2011), where resistance induction is involved (Schwan-Estrada et al., 2008) responsible for the activation of latent mechanisms of plant defense against pathogens by treatment with biotic or abiotic elicitor molecules (Pascholati, 2011).

Among the many resistance inducers, we can mention the use of fungi (Medeiros et al., 2014) as yeasts (Mello et al., 2011). Several defense mechanisms can be activated such as enzymes, such as peroxidase, important in cell lignification, polyphenoloxidase responsible for modifying phenols in toxic quinones and phenylalanine ammonia-lyase, predecessor of the synthesis of defenylpropanoids, involved in plant defense (Stangarlin et al., 2011), And one of the most important in the biosynthesis of lignin and phytoalexins (Kalaiarasan, 2009).

Another example would be the production of phytoalexins (Peiter-Beninca et al., 2008), which are antimicrobial compounds (Paschoalati \& Dalio, 2018) responsible for inhibiting germination and mycelial growth (Pascholati, 2011). 
In view of the above, the objective of this work was to investigate the potential of yeast in phytoalexin-glycine oxidase induction on the activity of peroxidase, polyphenol oxidase and phenylalanine ammonia-lyase in soybean cotyledons treated with different yeasts.

\section{Materials and Methods}

The assay for the evaluation of the phytoalexins and glycinolins induction and enzymatic activity in soybean cotyledons was conducted at the Phytopathology Laboratory of the State University of the West of Paraná (Unioeste), Campus of Marechal Cândido Rondon - PR, the same laboratory being the supplier of used yeasts.

The experimental design was completely randomized with six treatments (sterile distilled water, Cryptococcus laurentii (AH 03-1), Pichia guilliermondii (AH 16-2), Rhodotoru laglutinis (AH 14-3), Sporidiobolus johnsonii (AH 16-1) and Zygoascus hellenicus (AH 14-1)), and four replicates.

Soybean seeds of the cultivar M5947 IPRO were disinfested in 70\% alcohol and hypochlorite (3:1), then washed with running distilled water and seeded in plastic trays containing autoclaved sand at $120{ }^{\circ} \mathrm{C}$ for $2 \mathrm{~h}$. Daily watering was carried out with distilled water and kept in the growth chamber for about 10 days.

When freshly opened, the totally healthy cotyledons were detached, washed with distilled water, dried and in the abaxial region a section was made using a scalpel. The cut cotyledons were placed into Petri dishes containing filter paper moistened with sterile distilled water and five cotyledons were distributed per plate with the cuts facing upwards. A $20 \mu \mathrm{L}$ aliquot of the treatments was applied on each cut.

The petri dishes were kept dark in BOD at $25^{\circ} \mathrm{C}$ for $20 \mathrm{~h}$. After, the cotyledons were transferred to plastic vials containing $10 \mathrm{~mL}$ of sterile distilled water. The flasks remained at $150 \mathrm{rpm}$ on an orbital shaker for 1 hour for extraction of phytoalexin gliceoline.

Supernatant readings were performed at $285 \mathrm{~nm}$ in spectrophotometer and the five cotyledons of each replicate were weighed on analytical balance.

These same cotyledons were used with $4 \mathrm{~mL}$ of $0.01 \mathrm{M}$ serum phosphate $(\mathrm{pH}$ 6.0) and the liquid nitrogen in a porcelain mortar, the homogenate being centrifuged at $6,000 \mathrm{~g}$ for 20 minutes at $4{ }^{\circ} \mathrm{C}$ and the supernatant stored at $-20{ }^{\circ} \mathrm{C}$ for the accomplishment of the biochemical analyzes.

For the peroxidase activity the methodology described by Hammerschmidt et al. (1982) was used by mixing 100 $\mu \mathrm{L}$ of the supernatant and $900 \mu \mathrm{L}$ of the enzyme substrate with spectrophotometer readings for 2 minutes at 470 $\mathrm{nm}$.

To determine the polyphenoloxidase activity, the Duangmal and Apenten method (1999) was used, creating 900 $\mu \mathrm{L}$ of substrate for one enzyme and $100 \mu \mathrm{L}$ of supernatant. As readings, they were made in a spectrophotometer at $420 \mathrm{~nm}$ for 2 minutes. Both paraperoxidase and parapolyphenoloxidase, were expressed as absorbance $\min ^{-1}$ $\mathrm{mg}^{-1}$ protein.

For the activity of the phenylalanine ammonia-lyase was used the colorimetric quantification method of the trans-cinnamic acid released from the substrate, according to Umesha (2006), where $50 \mu \mathrm{L}$ of the supernatant was mixed in $450 \mu \mathrm{L}$ of Tris- $\mathrm{HCl} 0.025 \mathrm{M}$ buffer $\mathrm{pH} 8.8$ and $500 \mu \mathrm{L}$ of $0.05 \mathrm{M}$ phenylalanine solution were added and the mixture was incubated in a water bath at $40^{\circ} \mathrm{C}$ for $2 \mathrm{~h}$, and then $60 \mu \mathrm{L}$ of $5 \mathrm{M} \mathrm{HCl}$ was added to stop the reaction. The spectrophotometer was read at $290 \mathrm{~nm}$. The values were obtained by the difference of the sample and control.

The methodology of Bradford (1976) was used to determine the total important proteins in the calculation of the enzymes. $200 \mu \mathrm{L}$ of the supernatant, $600 \mu \mathrm{L}$ of $0.01 \mathrm{M}$ phosphate buffer $(\mathrm{pH}$ 6.0) and $200 \mu \mathrm{L}$ of Bradford reagent were added, the latter being added under stirring. After shaking, the samples were incubated for 10 minutes and read at $595 \mathrm{~nm}$ in a spectrophotometer. The absorbances obtained were plotted on a standard curve of bovine serum albumin.

The datas were submitted to analysis of variance and the means were compared by the Tukey test at $5 \%$ probability of error using the free software Genes (Cruz, 2013).

\section{Results and Discussion}

For phytoalexins, according to Figure 1, Cryptococcus laurentii yeasts (AH 03-1) and Zygoascus hellenicus (AH 14-1) were statistically different from the water, with respective phytoalexin values of $83.65 \%$ and $78.75 \%$ compared to water.

In a study accomplished by Stangarlin et al. (2010) using yeasts $S$. cerevisiae and $S$. boulardii in soy cotyledons, the authors found higher phytoalexin induction values for $S$. boulardii, concluding that it is an inducer, but 
according to the same authors, this does not exclude activity eliciting of $S$. cerevisiae, since this yeast presents components of the cell wall that can be inactivated with autoclave, which may justify the lowest verified induction.

Working with sorghum mesocotyls, Stangarlin et al. (2010) also verified an inductive effect by S. boulardii yeasts, supposedly due to metabolites released by them.

Wulff and Pascholati (1998) studying phytoalexins in sorghum mesocotyls observed the increase of the measurement of this compound using as $S$. cerevisiae yeast.

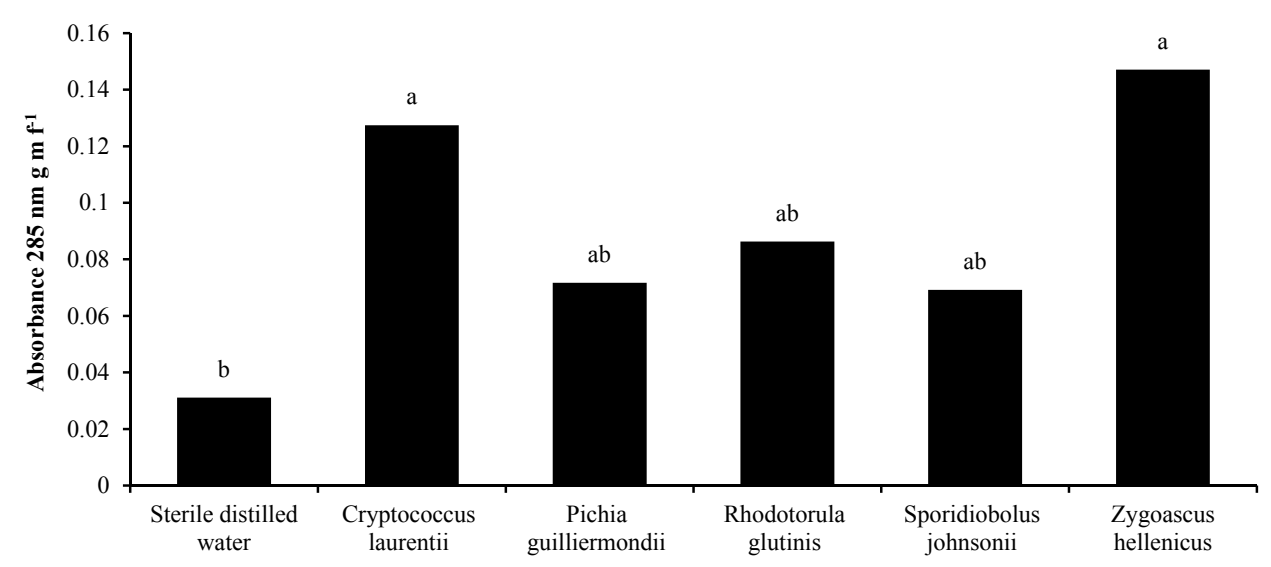

Figure 1. Induction of phytoalexin glycine in soybean cotyledons (Glycine max) with different yeasts (Cryptococcus laurentii (AH 03-1), Pichia guilliermondii (AH 16-2), Rhodotorula glutinis (AH 14-3), Sporidiobolus johnsonii (AH 16-1) and Zygoascus hellenicus (AH 14-1)). The averages of the same column letter did not differ statistically by the Tukey's test $(\mathrm{p}<0.05)$. CV $=18.37$

In relation to a peroxidase activity in soybean cotyledons only one Cryptococcus laurentii yeast (AH 03-1) appeared different from water, with an increase of $36.84 \%$ compared to it, according to Figure 2.

According to Viecelli et al. (2010), changes in the activity of the peroxidase enzyme refers to the susceptibility or resistance response to numerous patosystems. Resende et al. (2007) complements the claim that this enzyme is responsible for catalyzing an oxidation of phenolic alcohols to lignin, which causes the largest company against toxins released by pathogens.

In a study carried out by Formentini (2012), the initial activity of this enzyme may be related to the pre-disposition resistance. This same author states that the initial activity of this enzyme may be related to the pre-disposition to resistance and according to Stangarlin et al. (2011) the modification of the activity of this enzyme can indicate induction of resistance since the enzymes act preventively for the health of the plant, that is, making it impossible for the pathogen to transpose the cell wall. 


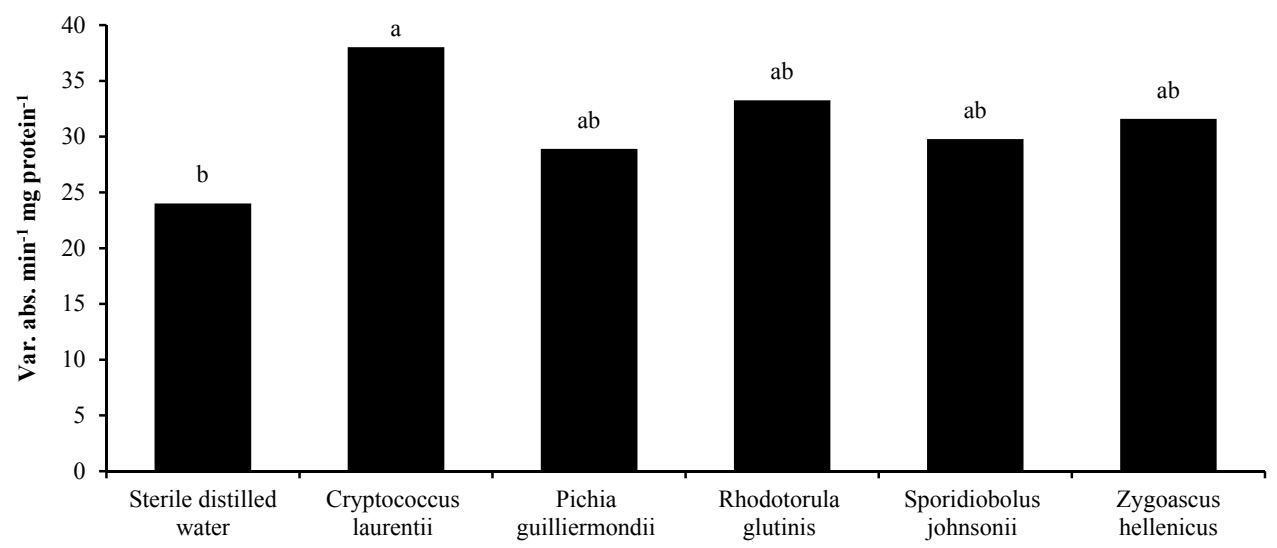

Figure 2. Peroxidase activity in soybean cotyledons treated with different yeasts (Cryptococcus laurentii (AH 03-1), Pichia guilliermondii (AH 16-2), Rhodotorula glutinis (AH 14-3), Sporidiobolus johnsonii (AH 16-1) and Zygoascus hellenicus (AH 14-1)). * Averages followed by the same lowercase letter in the column do not differ statistically by the Tukey test $(\mathrm{p}<0.05)$. $\mathrm{CV}=14.92$

For polyphenoloxidase, the activity was more significant in cotyledons treated with Pichia guilliermondii yeasts (AH 16-2), Rhodotorula glutinis (AH 14-3), Sporidiobolus johnsonii (AH 16-1) and Zygoascus hellenicus (AH $14-1$ ), which showed an increase of $33.33 \%, 28.00 \%, 33.33 \%$ and $33.33 \%$, respectively, in the activity of this enzyme compared to the water treatment (Figure 3).

In a study carried out by Khalid (2013), using $S$. cereviseae yeast in bean plants affected by Sclerotium rolfsii, an increase of peroxidase and polyphenoloxidase was observed and consequently the reduction of the disease due to the induction of resistance mechanisms.

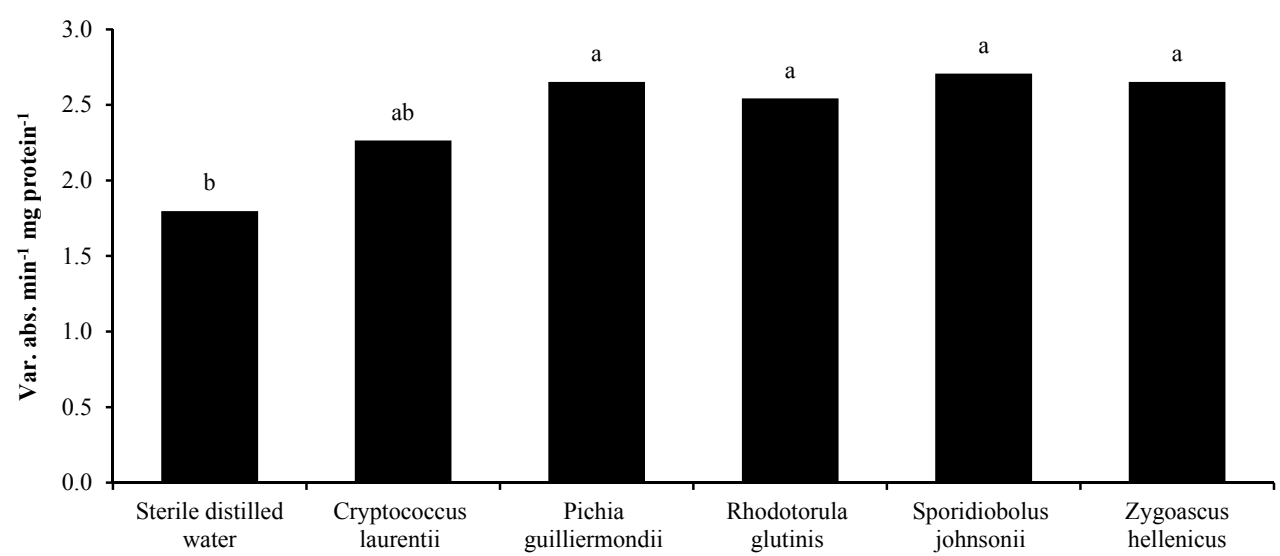

Figure 3. Activity of polyphenoloxidase in soybean cotyledons together with different yeasts (Cryptococcus laurentii (AH 03-1), Pichia guilliermondii (AH 16-2), Rhodotorula glutinis (AH 14-3), Sporidiobolus johnsonii

(AH 16-1) and Zygoascus hellenicus (AH 14-1)). The averages of the same column letter did not differ statistically by the Tukey's test $(\mathrm{p}<0.05)$. $\mathrm{CV}=12.33$

According to Figure 4, for the activity of phenylalanine ammonia-lyase the Pichia guilliermondii yeasts (AH 16-2), Rhodotorula glutinis (AH 14-3) and Sporidiobolus johnsonii (AH 16-1) were statistically equal to water, whereas the yeasts Cryptococcus laurentii (AH 03-1) and Zygoascus hellenicus (AH 14-1) presented an increase of $75.57 \%$ and $78.86 \%$, respectively, purchased from the water treatment, being statistically different.

Klessig and Malamy (1994) say that the activity of the phenylalanine ammonia-lyase enzyme prepares precursors for the biosynthesis of lignin and other phenolic compounds that are deposited as a reaction to 
infection, a fact that demonstrates the importance of the activity of this enzyme and how much it can contribute in the induction of resistances.

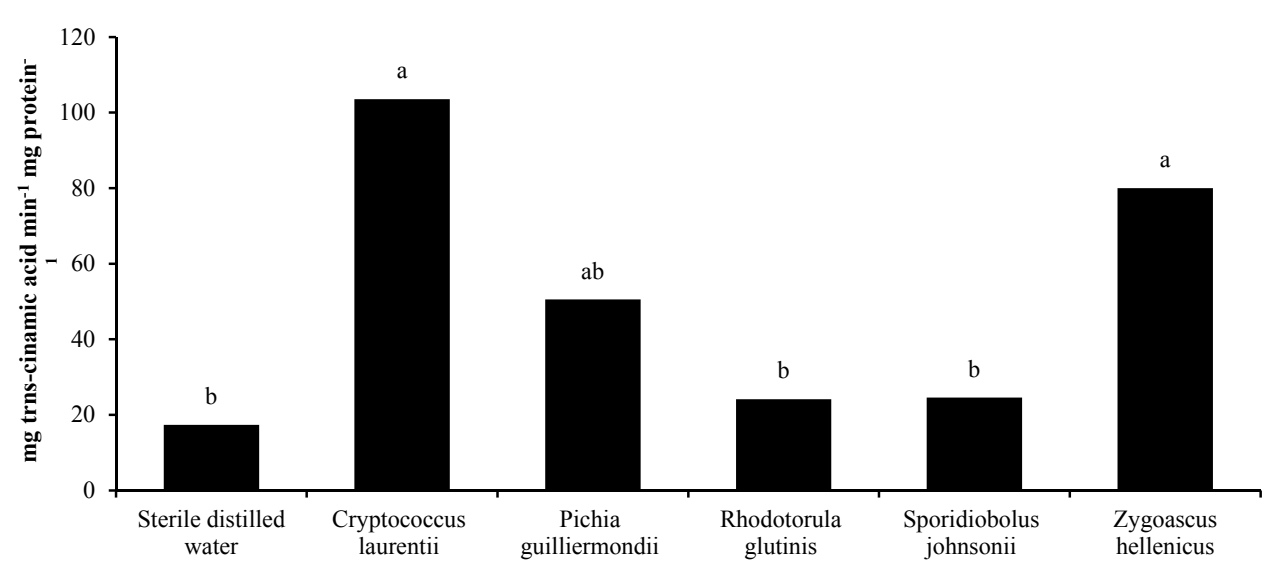

Figure 4. Activity of phenylalanine ammonia-lyase in soybean cotyledons treated with different yeasts (Cryptococcus laurentii (AH 03-1), Pichia guilliermondii (AH 16-2), Rhodotorula glutinis (AH 14-3), Sporidiobolus johnsonii (AH 16-1) and Zygoascus hellenicus (AH 14-1)). * Averages followed by the same lowercase letter in the column do not differ statistically by the Tukey test $(p<0.05)$. CV $=36.36$

According to Barros et al. (2010), the biofertilizers can alter the systemic resistance induced and the acquired systemic resistance, being that in its composition are the yeasts, which demonstrates the existence of inductive potential of resistance present in them, which Pascholati (1998) also describes the existence of eliciting activity in yeast.

Piccinin et al. (2005) observed studying $S$. cerevisiae properties in resistance induction considering this yeast an elicitor. In a study by Fialho et al. (2010) using $S$. cerevisiae yeast, the production of antimicrobial volatile organic compounds, based on alcohols and esters, has also been identified and may have action on defense mechanisms, indicating the potential of yeasts in the resistance induction.

Stangarlin and Pascholati (1994) state that yeasts promote the activation of plant defenses due to elicitation by compounds present in them and Gouvea et al. (2007) also report the yeast resistance induction capacity.

The increase of the activity of certain enzymes caused by the yeasts can be positive, since according to Romeiro and Garcia (2009), at the moment which the plant is exposed to a certain elicitor preventively, that is, before having contact with a certain pathogen, its tissues present a rapid and efficient reaction to the attempt to colonize the pathogen, which is advantageous.

\section{Conclusion}

Yeasts are able to induce the activity of phytoalexins gliceolines, peroxidase, polyphenoloxidase and phenylalanine ammonia-lyase in soy cotyledons revealing the action of elicitors present in these fungi.

\section{References}

Agrios, G. N. (2005). Plant Pathology (5th ed., pp. 207-248). San Diego: Elsevier Academic Press. https://doi.org/10.1016/B978-0-08-047378-9.50012-9

Barros, F. C., Sagata, E., Ferreira, L. C. C., \& Juliatti, F. C. (2010). Indução de resistência em plantas contra fitopatógenos. Bioscience Journal, 26(2), 231-239.

Bradford, M. M. (1976). A rapid and sensitive method for the quantitation of microgram quantities of protein utilizing the principle of protein-dye binding. Analytical Biochemistry, 72, 248-254. https://doi.org/ 10.1016/0003-2697(76)90527-3

Carneiro, S. M. T. P., Teixeira, M. Z., Nechar, R. M. C., Lonni, A. A., Rodrigues, M. R., \& Filippsen, L. (2011). Homeopatia: Princípios e aplicações na agroecologia. Londrina: IAPAR.

Cruz, C. D. (2013). Genes: A software package for analysis in experimental statistics and quantitative genetics. Acta Scientiarum. Agronomy, 35(3), 271-276. https://doi.org/10.4025/actasciagron.v35i3.21251 
Duangmal, K., \& Apenten, R. K. O. (1999). A comparative study of polyphenoloxidases from taro (Colocasia esculenta) and potato (Solanum tuberosum var. Romano). Food Chemistry, 64, 351-359. https://doi.org/ 10.1016/S0308-8146(98)00127-7

Fialho, M. B., Toffano, L., Pedroso, M. P., Augusto, F., \& Pascholati, S. F. (2010). Volatile organic compounds produced by Saccharomyces cerevisiae inhibit the in vitro development of Guignardia citricarpa, the causal agent of citrus black spot. World Journal of Microbiology and Biotechnology, 26(5), 925-932. https://doi.org/10.1007/s11274-009-0255-4

Formentini, H. M. (2012). Avaliação de indutores de resistência biótico, abiótico e extratos vegetais no controle de Meloidogyne incognita em tomateiro (Tese (Doutorado em Agronomia), Marechal Cândido Rondon PR, Universidade Estadual do Oeste do Paraná).

Gouvea, A., Mazzaro, S. M., PossentI, J. C., dos Santos, I., \& Stangarlin, J. R. (2007). Controle biológico de doenças em plantas pelo uso de leveduras. In T. N. Martin \& M. M. Montagner (Eds.), Sistemas de produção agropecuária (pp. 156-169). Dois Vizinhos: Universidade Tecnológica Federal do Paraná.

Hammerschimidt, T. R., Nucles, E. M., \& Kuc, J. (1982). Association of enhanced peroxidase activity with induced systemic resistance of cucumber to Colletotrichum lagenarium. Physiological Plant Pathology, 20, 73-82. https://doi.org/10.1016/0048-4059(82)90025-X

Hirakuri, M. H., \& Lazzarotto, J. J. (2014). O agronegócio da soja nos contextos mundial e brasileiro (Documentos 349, p. 70). Londrina: Embrapa Soja.

Juhász, A. C. P., Pádua, G. P., Wruck, D. S. M., Favoreto, L., \& Ribeiro, N. R. (2013). Desafios fitossanitários para a produção de soja. Defesa vegetal e sustentabilidade do agronegócio. Informe Agropecuário, 34(276), 66-75.

Kalaiarasan, P. (2009). Biochemical markers for identification of root knot nematode (Meloidogyne incognita) resistance in tomato. Journal of Agricultural Sciences, 22(3), 471-475.

Khalid, E. E. (2013). Biological controlo f bean damping-off caused by Sclerotium rolfsii. Egypt. J. Phytopathology, 42(1), 179-191. https://doi.org/10.21608/ejp.2014.96750

Klessig, D. F., \& Malamy, J. (1994). The salicylic acid signal in plants. Plant Molecular Biology, 26, 1439-1458. https://doi.org/10.1007/BF00016484

Medeiros, F. H. V., Monteiro, F. P., Freitas, M. A., Martins, S. J., Rodriguez, G. A., Laborde, M. C. F., ... Nogueira, C. C. A. (2014). Ganho de função em plantas mediadas por bactérias e fungos. In K. R. F. Schwan-Estrada, C. M. Silva, A. J. Maia, C. M. D. R. Faria \& J. C. T. Colella (Eds.), Indução de resistência em plantas a patógenos (Vol. 7, Cap. 6, pp. 93-120). Maringá: UEM/MPA.

Mello, M. R. F., Silveira, E. B., Viana, I. O., Guerra, M. L., \& Mariano, R. L. R. (2011). Uso de antibióticos e leveduras para controle da podridão-mole em couve-chinesa. Horticultura Brasileira, 29(1), 78-83. https://doi.org/10.1590/S0102-05362011000100013

Pascholati, S. F. (1998). Potencial de Saccharomyces cerevisiae e outros agentes bióticos na proteção de plantas contra patógenos (123 f. Tese (Livre Docência), Escola Superior de Agricultura "Luiz de Queiroz", Universidade de São Paulo, Piracicaba).

Pascholati, S. F. (2011). Fisiologia do parasitismo: Como as plantas se defendem dos patógenos. In L. Amorim, J. A. M. Rezende \& A. Bergamin Filho (Eds.), Manual de Fitopatologia: Princípios e Conceitos (4th ed., Vol. 1, pp. 593-636). São Paulo: Agronômica Ceres.

Pascholati, S. F., \& Dalio, R. J. D. (2018). Fisiologia do parasitismo: Como as plantas se defendem dos patógenos. In L. Amorim, J. A. M. Resende, \& A. Bergamin Filho (Eds.), Manual de fitopatologia: princípios e conceitos. Ouro fino: Agronômica Ceres.

Peiter-Beninca, C., Franzener, G., Assi, L., Iurkiv, L., Eckstein, B., Costa, V., ... Schwan-Estrada, K. R. F. (2008). Indução de fitoalexinas e atividade de peroxidases em sorgo e soja tratados com extratos de basidiocarpos de Pycnoporus sanguineus. Arquivo Instituto Biológico, 75, 285-292.

Piccinin, E., Di Piero, R. M., \& Pascholati, S. F. (2005). Efeito de Saccharomyces cerevisiae na produtividade de sorgo e na severidade de doenças foliares no campo. Fitopatologia Brasileira, 30(1), 5-9. https://doi.org/ 10.1590/S0100-41582005000100001 
Resende, M. L. V., Barreti, P. B., Medeiros, F. C. L., Silva, D. D. da, Pereira, R. B., Lins, S. R. O., ... Campos, M. A. (2007). Percepção e transdução de sinais para a ativação de respostas de defesa em plantas contra patógenos. Revisão Anual de Patologia de Plantas, 15, 173-242.

Romeiro, R. S., \& Garcia, F. A. O. (2009). Indução de resistência em plantas a patógenos por eliciadores de natureza bacteriana. Biocontrole de doenças de plantas: Uso e perspectivas. Jaguariúna.

Schwan-Estrada, K. R. F., Stangarlin, J. R., \& Pascholati, S. F. (2008). Mecanismos bioquímicos de defesa vegetal. In S. F. Pascholati, B. Leite, J. R. Stangarlin, \& P. Cia (Ed.), Interação Planta Patógeno: Fisiologia, bioquímica e biologia molecular. Piracicaba: FEALQ.

Stangarlin, J. R., \& Pascholati, S. F. (1994). Proteção de plântulas de milho pipoca contra Exserohilum turcicum pelo uso de Saccharomyces cerevisiae. Summa Phytopathologica, 20(1), 16-21.

Stangarlin, J. R., Kuhn, O. J., Toledo, M. V., Portz, R. L., Schwan-Estrada, K. R. F., \& Pascholati, S. F. (2011). A defesa vegetal contra fitopatógenos. Scientia Agraria Paranaensis, 10, 18-46.

Stangarlin, J. R., Schulz, D. G., Franzener, G., Assi, L. SchwanEstrada, K. R. F., \& Kuhn, O. J. (2010). Indução de fitoalexinas em soja e sorgo por preparações de Saccharomyces boulardii. Arquivos do Instituto Biológico, 77(1), 91-98. https://doi.org/10.1590/1808-1657v77p0912010

Umesha, S. (2006). Phenylalanine ammonia-lyase activity in tomato seedlings and its relationship to bacterial canker disease resistance. Phytoparasitica, 34(1), 68-71. https://doi.org/10.1007/BF02981341

Viecelli, C. A., Stangarlin, J. R., Kuhn, O. J., \& Schwan-Estrada, K. R. F. (2010). Indução de resistência em feijoeiro a mancha angular por extratos de micélio de Pycnoporus sanguineus. Summa Phytopathologica, 36(1), 73-80. https://doi.org/10.1590/S0100-54052010000100013

Wulff, N. A., \& Pascholati, S. F. (1998). Preparações de Saccharomyces cerevisiae elicitoras de fitoalexinas em mesocótilos de sorgo. Scientia Agricola, 55(1), 138-143. https://doi.org/10.1590/S0103-90161998000 100022

\section{Copyrights}

Copyright for this article is retained by the author(s), with first publication rights granted to the journal.

This is an open-access article distributed under the terms and conditions of the Creative Commons Attribution license (http://creativecommons.org/licenses/by/4.0/). 